\title{
Single and Repeated Stress-Induced Modulation of Phospholipase C Catalytic Activity and Expression: Role in LH Behavior
}

\author{
Yogesh Dwivedi*,', Amal C Mondal', Hooriyah S Rizavi', Pradeep K Shukla' and Ghanshyam N Pandey' \\ 'Department of Psychiatry, University of Illinois at Chicago, Chicago, IL, USA
}

\begin{abstract}
PI-PLC, a critical enzyme of the phosphoinositide (PI) signaling pathway, mediates many physiological functions in the brain, including cellular plasticity. Stress-induced learned helplessness $(\mathrm{LH})$ in animals serves as a model of behavioral depression. Recently, we observed that repeated stress prolongs the duration of $\mathrm{LH}$ behavior in rats, enabling us to compare neurobiologic abnormalities in acute and chronic depression. Here we examine whether LH behavior is associated with alterations in phospholipase C (PLC), and whether repetition of inescapable shock has similar or dissimilar effects on PLC to those of the single-stress paradigm. Rats were exposed to inescapable shock either once on day I, or twice, on days I and 7. Rats were tested for escape latency on days 2 and 4 after day I inescapable shock or on days 2, 8, and I 4 after day I and 7 inescapable shock. PI-PLC activity and mRNA and protein expression of three different PLC isozymes were determined in the frontal cortex and hippocampus. Higher escape latencies were observed in LH rats tested on day 2 after single inescapable shock and on day 14 after repeated inescapable shock. Single inescapable shock reduced PI-PLC activity in the frontal cortex and hippocampus of LH rats. On the other hand, repeated inescapable shock not only reduced PI-PLC activity in these brain areas of $\mathrm{LH}$ rats but also selectively decreased the expression of PLC $\beta_{1}$ and PLC $\gamma_{1}$ isozymes. Our results suggest different responsiveness at the level of PI-PLC after single vs repeated stress, and that reductions in PLC may be critical in the pathophysiology of depression and other stress-related disorders.

Neuropsychopharmacology (2005) 30, 473-483, advance online publication, 10 November 2004; doi: I 0. I 038/sj.npp. I 300605
\end{abstract}

Keywords: depression; stress; behavior; animal model; mRNA; immunolabeling

\section{INTRODUCTION}

Depression is a major public health concern, afflicting about nine million people each year in the United States alone. Despite many years of research, the molecular and cellular mechanisms associated with depression are not clear.

The learned helplessness ( $\mathrm{LH}$ ) model is considered one of the most valid and reliable animal models of depression. It represents the theoretical basis of the origin and development of depression, as the model is a combination of cognitive and neurovegetative abnormalities and genetic susceptibility (Jesberger and Richardson, 1985; Henn et al, 1993; Nestler et al, 2002). In this animal model, however, the behavioral deficits can be seen for only a few days (2-3 days). Very recently, we developed an animal model of

\footnotetext{
*Correspondence: Dr Y Dwivedi, Department of Psychiatry, University of Illinois at Chicago, 1601 West Taylor Street, Chicago, IL 606 I2, USA, Tel: + I 312413 4557, Fax: + I 3123553857 ,

E-mail: ydwivedi@psych.uic.edu

Received I July 2004; revised 9 September 2004; accepted 28 September 2004

Online publication: 5 October 2004 at http://www.acnp.org/citations/ Npp I00504040306/default.pdf
}

depression in rats using an LH paradigm in which repeated stress prolongs the duration of LH behavior (Dwivedi et al, 2004). This is critical, since the neurobiology and the response to chronic/recurrent depression may be different from that in acute depression.

An emerging hypothesis suggests that depression may be associated with neuroplasticity and cellular adaptation (Duman et al, 2000), which may be due to the convergence of downstream events beyond the receptors at the level of intracellular signaling molecules (Nestler et al, 2002). Although several neurotransmitter systems have been studied in LH animals, including norepinephrine (Weiss et al, 1970; Minor et al, 1988; Petty et al, 1993), dopamine (Anisman and Zacharko, 1992), GABA (Drugan et al, 1989; Petty et al, 1992), serotonin (5HT) (Petty and Sherman, 1983; Maier et al, 1995; Maswood et al, 1998), adenosine (Minor et al, 2001), NMDA (Grahn et al, 2002), and opiate (Drugan and Maier, 1983), the role of signaling molecules beyond the receptors in LH behavior has not been fully investigated. In this regard, recently we showed that protein kinase A, a phosphorylating enzyme in the adenylyl cyclasecAMP signaling mechanism, is significantly altered in the frontal cortex and hippocampus of LH rats, the effect being 
greater in the repeated-stress paradigm than in the acutestress paradigm (Dwivedi et al, 2004).

PLC is a crucial enzyme of the phosphoinositide (PI) signaling mechanism that hydrolyzes phosphatidylinositol 4,5-bisphosphate into inositol 1,4,5-trisphosphate $\left(\mathrm{IP}_{3}\right)$ and diacylglycerol (DAG) (reviewed by Rebecchi and Pentyala, 2000). $\mathrm{IP}_{3}$ mobilizes $\mathrm{Ca}^{2+}$ from intracellular sources after binding with $\mathrm{IP}_{3}$ receptors; DAG activates the phosphorylating enzyme protein kinase C (Dekker et al, 1995). These events mediate cellular activation and subsequent biological responses, including neurotransmitter release, cell growth, differentiation, neuronal development, and plasticity. Recently, we showed that antidepressants and anxiolytics differentially modulate PLC in rat brain (Dwivedi et al, 2002) and that PLC is involved in suicidal behavior (Pandey et al, 1999). It is therefore of interest and important to examine whether LH behavior is associated with a modulation of PLC and whether these effects are similar or dissimilar in acute- and repeated-stress paradigms.

To characterize the role of PLC in LH behavior, we systematically determined PI-PLC catalytic activity and the expression of PLC isozymes at transcriptional and translational levels in the frontal cortex and hippocampus of rats subjected to two different stress paradigms. In addition, to investigate whether the changes in PLC are specifically associated with LH behavior, in the present study we included those rats in which the LH behavior had dissipated after the single stress.

\section{MATERIALS AND METHODS}

\section{Animals}

Virus-free male Holtzman rats (Harlan Sprague-Dawley Laboratories, Indianapolis, IN, USA) were housed in individual cages under standard laboratory conditions (temperature $21 \pm 1^{\circ} \mathrm{C}$, humidity $55 \pm 5 \%, 12$-h light/dark cycle). Animals were provided free access to food and water. Animals were housed for 3 weeks before the experiment, and the body weight was $325-375 \mathrm{~g}$ at the start of the experiment. All the experiments were performed between 0800 and $1000 \mathrm{~h}$. Experimental procedures were approved by the Animal Care Committee of the University of Illinois at Chicago.

\section{Behavioral Procedures}

Learned helplessness induction by inescapable shock (IS) and escape testing were performed by the procedures described earlier by us (Dwivedi et al, 2004). Rats were divided into three groups designated as group A, group B, and group C. Group A rats were given IS on day 1 and were tested for escape latency on day 2. Group B rats were given IS on day 1 and tested for escape latency on day 2; the rats were tested again on day 4 . Group C rats were given IS on day 1 and tested for escape behavior on day 2; these animals were given another IS on day 7 and tested for escape behavior on day 8 and on day 14. All the animals were decapitated $24 \mathrm{~h}$ after the last escape testing.

\section{Inescapable Shock Treatment}

The rats were placed in Plexiglas tubes with the rat's tail extending from the rear of the tube. The tail was attached with tape to a Plexiglas rod. Shocks were delivered by means of a computer-controlled constant-current shock generator (Model ENV-410B, Med Associates, Lafayette, IN, USA) to electrodes augmented with electrode paste to the rat's tail. The inescapable shock consisted of 100 random shocks delivered for $5 \mathrm{~s}$ at the intensity of $1.0 \mathrm{~mA}$, with a mean interval of $60 \mathrm{~s}$. Another group of rats (to be used as tested control) was placed in Plexiglas tubes, but was not subjected to shocks.

\section{Shuttle Box Escape Testing}

This was conducted in a shuttle box $\left(70 \times 20 \times 20 \mathrm{~cm}^{3}\right)$ (Med Associates, Lafayette, IN, USA). The shuttle box contained an electrified grid floor and was divided into two equal chambers with an arched doorway in the center $\left(5 \times 7 \mathrm{~cm}^{2}\right)$. Footshock was delivered through the grid floor by a shock generator (Model ENV-413, Med Associates, Lafayette, IN, USA). The shuttle box was contained in a soundproof cubicle with an exhaust fan, and a 6-W lamp located in the center of the roof provided illumination. The shuttle box escape testing began with five trials (FR-1), during which a single crossing would terminate the shocks. This was followed by 25 trials (FR-2) in which a rat had to cross from one side of the shuttle box to the other and come back to terminate the shocks. Shocks were terminated automatically after $30 \mathrm{~s}$ if there was no response within that time. The intensity of the shocks was $0.6 \mathrm{~mA}$. The shocks were presented on a variable schedule. Shuttle escape latencies and escape failures were recorded automatically by a computer attached to the generator and shuttle box. An FR-2 trial with escape latency $>20 \mathrm{~s}$ was defined as an escape failure. Rats having 10-25 failures to escape were considered to be deficient in the escape response.

Rats were divided into two groups based on the mean latency observed after FR-2: (1) those rats in which the mean latency was $\geqslant 20 \mathrm{~s}$ (termed learned helpless (LH)) and (2) those in which the mean latency was $<20 \mathrm{~s}$ (termed as non-learned helpless (NLH)). In our study, we found that about $50 \%$ of all the rats tested became LH rats. In group C, in which IS was given on day 1 and again on day 7, most of the rats who initially did not show an escape deficit (NLH) remained NLH even after the second shock paradigm; only a few showed a mean latency $\geqslant 20 \mathrm{~s}$ after the second paradigm. These rats were not included in the present study. The rats that were confined to Plexiglas tubes but were not shocked were also tested and termed as the tested control (TC). Groups A, B, and C contained eight LH, seven $\mathrm{NLH}$, and eight TC rats.

Rats were decapitated $24 \mathrm{~h}$ after the last escape testing, as mentioned earlier. Trunk blood was collected on ice, centrifuged, and the plasma was stored at $-80^{\circ} \mathrm{C}$. Plasma corticosterone levels were measured by a commercially available radioimmunoassay kit (ICN Biomedical Inc., Cleveland, OH, USA). Brains were removed quickly. The various brain areas were dissected on ice and immediately stored at $-80^{\circ} \mathrm{C}$ until analyzed.

\section{Determination of PI-PLC Activity}

PI-PLC activity was measured in membrane and cytosol fractions of the cortex and hippocampus by the enzymatic 
assay procedures described earlier (Dwivedi et al, 2000) in the presence of $5 \mu \mathrm{g}$ protein and phosphatidylinositol 4,5 bisphosphate $\left(\mathrm{PIP}_{2}\right)$ as substrate $\left(50 \mu \mathrm{M}\right.$ unlabeled $\mathrm{PIP}_{2}$, $2.0 \mu \mathrm{Ci} / \mathrm{ml}\left[{ }^{3} \mathrm{H}\right] \mathrm{PIP}_{2}$, and $0.5 \mathrm{mg} / \mathrm{ml}$ cetrimide). After termination of the reaction, radioactivity was counted. PIPLC activity is expressed as the amount of $\left[{ }^{3} \mathrm{H}\right] \mathrm{IP}_{3}$ formed $(\mathrm{dpm}) / \mathrm{min} / \mathrm{mg}$ protein.

\section{Immunolabeling of PLC $\beta_{1}, \gamma_{1}$, and $\delta_{1}$ Isozymes}

The procedure and characterization of the immunolabeling of PLC isozymes have been described earlier by us (Dwivedi et al, 2000). Equal volumes of protein samples (membrane or cytosol fractions; $20 \mu \mathrm{l}$ containing $30 \mu \mathrm{g}$ protein) were resolved onto $7.5 \%(\mathrm{w} / \mathrm{v})$ polyacrylamide gel and subsequently transferred to an ECL nitrocellulose membrane (Amersham, Arlington Heights, IL, USA). Membranes were incubated for $1 \mathrm{~h}$ with primary monoclonal antibody (antiPLC $\beta_{1}, \gamma_{1}$, or $\delta_{1}$ ) at a dilution of 1:1000 and subsequently with horseradish-peroxidase-linked secondary antibody (anti-mouse IgG; $1: 3000$ ) for $1 \mathrm{~h}$ at room temperature. To normalize the data, $\beta$-actin level was measured in the same immunoblot using $\beta$-actin as the primary monoclonal antibody (1:5000 for $2 \mathrm{~h}$ ) and anti-mouse IgG (1:5000 for $2 \mathrm{~h}$ ) as the secondary antibody. The optical densities of the bands on the autoradiograms were quantified using the Loats Image Analysis System (Westminster, MD, USA), and the optical density of each PLC isozyme band was corrected by the optical density of the corresponding $\beta$-actin band.

\section{Determination of mRNA Levels of PLC $\beta_{1}$ and $\gamma_{1}$ Isozymes by Competitive Reverse Transcriptase Polymerase Chain Reaction (RT-PCR)}

The procedure for determining the mRNA levels of PLC isozymes in rat brain has been described in detail earlier (Dwivedi et al, 2002). The primer pairs were designed to allow amplification of 532-847 base pairs (bp): forward, $5^{\prime}$ TTT TCG GCA GAC CGG AAG CGA, and reverse, $5^{\prime}$-TGC TGT TGG GCT CGT ACT TCT (GenBank accession \#M20636) for PLC $\beta_{1}$; and 506-877 bp: forward, 5'-AGG ATC GTA TAT CAG CCA AGG A, and reverse, $5^{\prime}$-AGT ATG GCT CCT CAA TCT CTC G (GenBank accession \#NM013187) for PLC $\gamma_{1}$. The specificity of the PLC $\beta_{1}$ and $\gamma_{1}$ mRNA products was checked by sequencing the amplified area with the Sequenase Version 2.0 DNA Sequencing Kit using HindIII and EcoRI, which produced fragments of the expected size.

The detailed procedures for the preparation of internal standards (cRNA) have been described earlier (Dwivedi et al, 2002). Each internal standard template was generated by site-directed mutagenesis to introduce a BglII restriction site. The internal primer sequences for PLC $\beta_{1}$ and $\gamma_{1}$ were as follows: PLC $\beta_{1}$ (645-668 bp): 5'-CCT GAA AGAT CTT CCC CGA CC; PLC $\gamma_{1}$ (689-706 bp): $5^{\prime}$-TGG ACC TTC $A \mathrm{G} A$ TCT TGG AAA CCA. The underlined bases indicate the $\overline{B g l I I}$ restriction site, whereas bold and italicized bases indicate the mutation sites.

Decreasing concentrations of PLC $\beta_{1}$ or $\gamma_{1}$ internal standard cRNA were added to $1 \mu \mathrm{g}$ of total RNA isolated from cortices or hippocampi. After termination of the RT reaction, cDNA aliquots containing reverse transcribed materials were amplified with Hot Tub DNA polymerase in the Thermal Cycler (9600, Perkin-Elmer). Trace amounts of $\left.{ }^{32} \mathrm{P}\right] \mathrm{dCTP}(0.5-1 \mu \mathrm{Ci} / \mathrm{sample})$ were included during the PCR step for subsequent quantification. The PCR mixture was amplified for 26 cycles. Following amplification, aliquots were digested with $B g l \mathrm{II}$ in triplicate and run on to $1.5 \%$ agarose gel electrophoresis. The results are expressed as attomoles/ $\mu \mathrm{g}$ of total RNA.

\section{RESULTS}

\section{Escape Latencies and Escape Failures}

We observed no significant differences in mean escape latencies after the FR-1 trials in all experimental paradigms (data not shown). Significant differences were observed in escape latencies among TC, NLH, and LH rats after the FR-2 trials. In group A (IS on day 1 and escape test on day 2), LH rats showed a significantly higher mean escape latency $(P<0.001)$ than NLH or TC rats, whereas the escape latency of NLH rats was not significantly different from that of TC rats $(P=0.86)$. The escape latencies (in seconds) in group $\mathrm{A}$ rats were as follows: $\mathrm{TC}=6.4 \pm 1.8 ; \mathrm{NLH}=7.2 \pm 3.7$; $\mathrm{LH}=23.6 \pm 3.3$. Similarly, in group $\mathrm{B}$ (IS on day 1 and escape test on day 2 and again on day 4 ), the mean escape latency was significantly higher on day 2 in LH rats $(P<0.001)$ as compared with TC or NLH rats $(\mathrm{TC}=5.7 \pm 2.8 ; \mathrm{NLH}=4.2 \pm 2.1 ; \mathrm{LH}=25.3 \pm 3.5)$; however, on day 4, the escape latency of the LH rats was similar to that of $\mathrm{NLH}$ or $\mathrm{TC}$ rats $(\mathrm{TC}=5.2 \pm 1.2 ; \mathrm{NLH}=4.5 \pm 1.9$; $\mathrm{LH}=8.2 \pm 3.3$ ). In group C (IS on days 1 and 7 and escape latency determined at three different time intervals: days 2, 8 , and 14), the mean escape latency was significantly higher in LH $(P<0.001)$ rats as compared with the NLH group at all time intervals. The mean latencies at the different time intervals in group $\mathrm{C}$ rats were as follows: day 2: $\mathrm{TC}=6.1 \pm 3.0 ; \quad \mathrm{NLH}=4.9 \pm 1.8 ; \quad \mathrm{LH}=25.1 \pm 3.5 ; \quad$ day 8 : $\mathrm{TC}=6.4 \pm 2.7 ; \quad \mathrm{NLH}=4.8 \pm 2.1 ; \mathrm{LH}=25.2 \pm 3.8 ;$ and day 14: $\mathrm{TC}=4.3 \pm 2.2 ; \mathrm{NLH}=4.9 \pm 2.4 ; \mathrm{LH}=26.3 \pm 3.2$. None of the groups showed any significant differences in mean escape latency between TC and NLH rats.

The escape failures in LH rats were significantly more numerous in group $\mathrm{A}$ and $\mathrm{C}$ rats, whereas no significant change was observed in group B rats. The number of escape failures in the different groups of rats was as follows: group A rats: $\mathrm{TC}=2.1 \pm 1.1 ; \quad \mathrm{NLH}=2.7 \pm 1.4 ; \quad \mathrm{LH}=18.1 \pm 2.5$ $(\mathrm{df}=2,20, \mathrm{~F}=192, P<0.001)$; group $\mathrm{B}$ rats: $\mathrm{TC}=3.0 \pm 1.3$; $\mathrm{NLH}=3.4 \pm 1.7 ; \quad \mathrm{LH}=3.6 \pm 0.9 \quad(\mathrm{df}=2,20, \quad \mathrm{~F}=0.47, \quad P=$ $0.64)$; and group $\mathrm{C}$ rats: $\mathrm{TC}=2.2 \pm 1.0 ; \mathrm{NLH}=3.3 \pm 1.1$; $\mathrm{LH}=19.0 \pm 3.5(\mathrm{df}=2,20, \mathrm{~F}=137, P<0.001)$.

\section{Corticosterone Levels}

Plasma corticosterone levels were measured in rats of groups $\mathrm{A}$ and $\mathrm{C}$ and were as follows $(\mathrm{ng} / \mathrm{ml})$ : group $\mathrm{A}$ rats: $\mathrm{TC}=257 \pm 86, \mathrm{NLH}=245 \pm 99, \mathrm{LH}=342 \pm 100$; group $\mathrm{C}$ rats: $\mathrm{TC}=269 \pm 116, \mathrm{NLH}=253 \pm 169, \mathrm{LH}=384 \pm 85$. Plasma corticosterone levels did not differ among TC, NLH, and LH rats either in group $\mathrm{A}(\mathrm{df}=2,20, \mathrm{~F}=2.38, P=0.11)$ or in group $\mathrm{C}(\mathrm{df}=2,20, \mathrm{~F}=2.49, P=0.10)$. 


\section{PI-PLC Activity}

PI-PLC activity was determined in membrane and cytosol fractions of frontal cortex and hippocampus obtained from TC, LH, and NLH rats of group A (IS on day 1 and escape test on day 2), group B (IS on day 1 and escape test on day 2 and again on day 4), and group C (IS on days 1 and 7 and escape test on days 2, 8, and 14). As can be seen in Figure 1 , PI-PLC activity was higher in both membrane and cytosol fractions of hippocampus than of the frontal cortex. A comparison of TC, LH, and NLH rats of group A showed that PI-PLC activity was significantly decreased in membrane and cytosol fractions of the frontal cortex and hippocampus of LH rats as compared with TC or NLH rats, whereas no significant differences were observed between $\mathrm{NLH}$ and TC rats (Figure 1). On the other hand, PI-PLC activity was not significantly different among TC, NLH, and $\mathrm{LH}$ rats of group $\mathrm{B}$, either in the frontal cortex or hippocampus (Figure 1). When rats were given repeated shocks and tested on day 14 (group C rats), it was observed that PI-PLC activity was significantly decreased in mem- brane and cytosol fractions of the frontal cortex and hippocampus of $\mathrm{LH}$ rats, the magnitude of the decrease being greater than that observed with group A rats (Figure 1).

\section{Immunolabeling of PLC Isozymes}

The immunolabeling of the various PLC isozymes (PLC $\beta_{1}$, $\delta_{1}$, and $\gamma_{1}$ ) was determined in the same membrane and cytosol fractions of frontal cortex and hippocampus in which PI-PLC activity was determined. As in our earlier reports (Dwivedi et al, 2000, 2002), in the present study it was observed that PLC $\beta_{1}$ migrated to $150 \mathrm{kDa}$, whereas PLC $\delta_{1}$ and $\gamma_{1}$ migrated to 85 and $145 \mathrm{kDa}$, respectively (Figure 2). The molecular mass of $\beta$-actin, used as a housekeeping protein, was $46 \mathrm{kDa}$. As we reported recently (Dwivedi et al, 2004), the immunolabeling of $\beta$-actin in the frontal cortex and hippocampus did not change after shock treatment.

The LH behavior-associated effects on the immunolabeling of PLC isozymes in membrane and cytosol fractions of
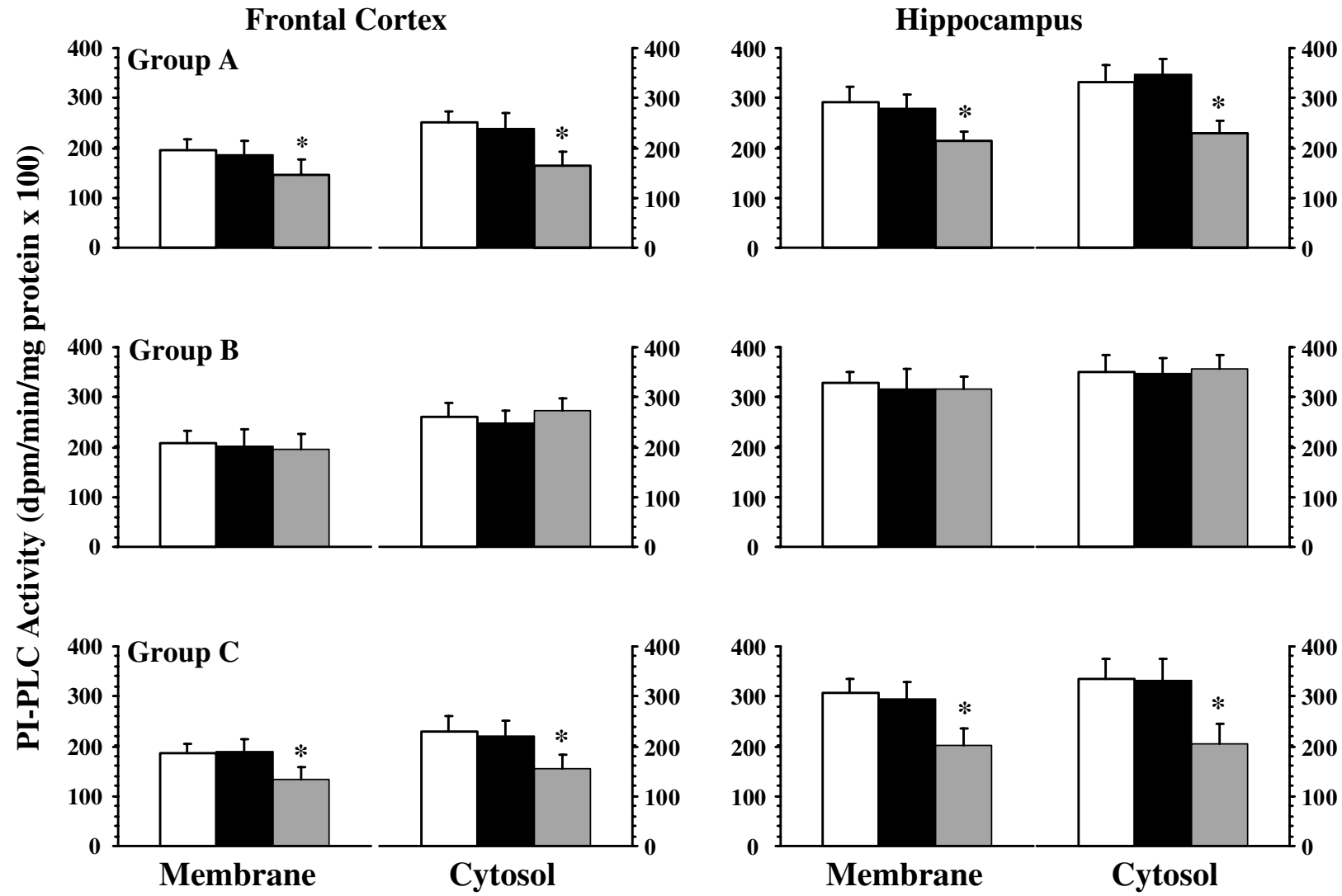

Figure I PI-PLC activity in membrane and cytosol fractions of the frontal cortex and hippocampus of groups A (given inescapable shock on day I and tested for escape latency on day 2), B (given inescapable shock on day I and tested for escape latency on day 4), and C (given inescapable shock on day I and tested for escape latency on day 2; rats were again given shock on day 7 and tested for escape latency on day 8, and re-tested on day 14 ); each comprised of TC, NLH, and LH rats. Rats were decapitated $24 \mathrm{~h}$ after the last testing. Values are means \pm SD. Overall group differences in PI-PLC activity in different groups were as follows: Group $A$ (frontal cortex: membrane, $\mathrm{df}=2,20, \mathrm{~F}=9.2, P=0.00 \mathrm{I}$; cytosol, $\mathrm{df}=2,20, \mathrm{~F}=22.59, P<0.00 \mathrm{I}$; hippocampus: membrane, $d f=2,20, F=20.16, P<0.00 I$; cytosol, $d f=2,20, F=34.45, P<0.00 I$ ); Group $B$ (frontal cortex: membrane, $d f=2,20, F=0.2, P<0.77$; cytosol, $\mathrm{df}=2,20, \mathrm{~F}=2.0, P=0.16$; hippocampus: membrane, $\mathrm{df}=2,20, \mathrm{~F}=0.48, P=0.62$; cytosol, $\mathrm{df}=2,20, \mathrm{~F}=0.19, P=0.82$ ); and $\mathrm{Group} C$ (frontal cortex: membrane, $\mathrm{df}=2,20, \mathrm{~F}=12.45, P<0.00 \mathrm{I}$; cytosol, $\mathrm{df}=2,20, \mathrm{~F}=14.73, P<0.00 \mathrm{I}$; hippocampus: membrane, $\mathrm{df}=2,20, \mathrm{~F}=24.47, \mathrm{P}<0.00 \mathrm{I}$; cytosol, $\mathrm{df}=2,20, \mathrm{~F}=26.89, P<0.00 \mathrm{I}) . * P<0.00 \mathrm{I}$ as compared with $\mathrm{TC}$. 


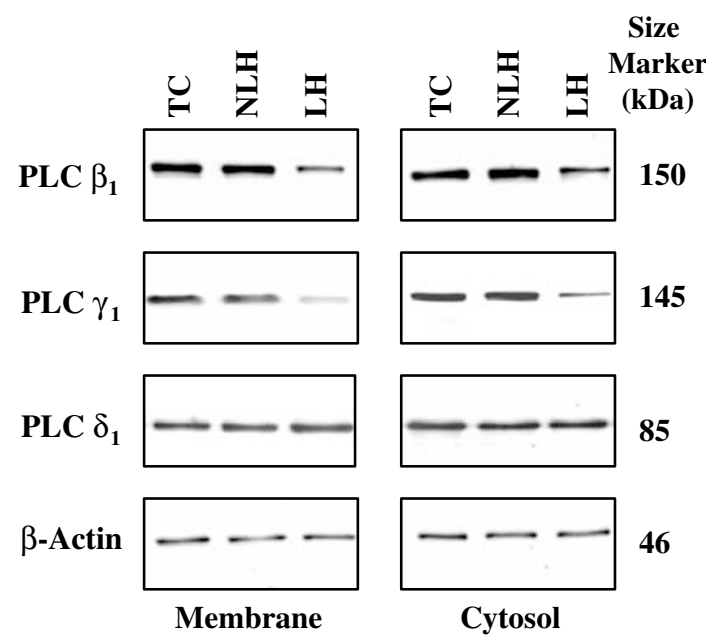

Figure 2 Representative Western blots of PLC isozymes in membrane and cytosol fractions of the frontal cortex obtained from group $C$ rats (given inescapable shock on day I and tested for escape latency on day 2; rats were again given shock on day 7 and tested for escape latency on day 8 , and re-tested on day 14 ), comprised of TC, NLH, and LH rats. Rats were decapitated $24 \mathrm{~h}$ after the last testing. Protein samples $(30 \mu \mathrm{g})$ were electrophoresed on a 7.5\% polyacrylamide gel, followed by electrotransfer to a nitrocellulose membrane. The blots were probed with monoclonal anti-PLC $\beta_{1}, \delta_{1}$, or $\gamma_{1}$ antibodies ( I: I 000 dilution). The molecular weights for the PLC $\beta_{1}, \gamma_{1}$, and $\delta_{1}$ isozymes were 150,145 , and $85 \mathrm{kDa}$, respectively. The blots were stripped and reprobed with $\beta$-actin antibody ( I:5000 dilution). $\beta$-Actin migrated to $46 \mathrm{kDa}$. Ratios of the optical densities of PLC $\beta_{1}, \delta_{1}$, or $\gamma_{1}$ to the optical density of $\beta$-actin were calculated.

the frontal cortex of group A rats (IS on day 1 and tested for escape latency on day 2) are given in Figure 3. In this group of rats, no significant differences among $\mathrm{LH}, \mathrm{NLH}$, and TC rats were observed in the immunolabeling of PLC $\beta_{1}, \delta_{1}$, or $\gamma_{1}$ isozyme in membrane or cytosol fractions of the frontal cortex or hippocampus. Similarly, group B rats (given IS on day 1 and tested for escape latency on day 4) did not show significant differences in the immunolabeling of any of the PLC isozymes, either in the frontal cortex or hippocampus. When PLC isozyme protein levels were determined in group $C$ rats (IS on days 1 and 7 and escape test on day 14), the immunolabeling of PLC $\beta_{1}$ and PLC $\gamma_{1}$ were significantly decreased in both membrane and cytosol fractions of the frontal cortex and hippocampus of LH rats as compared with NLH or TC rats (Figure 3 ).

\section{mRNA Levels of PLC Isozymes}

Since PI-PLC activity was decreased in LH rats after both single and repeated stress, but specific PLC isozymes were decreased only after repeated stress, we determined the LH behavior-associated effects on the transcriptional regulation of PLC $\beta_{1}$ and $\gamma_{1}$ isozymes in all groups of rats. Representative gel electrophoreses of PLC $\beta_{1}$ and $\gamma_{1}$ are given in Figure 4. It was observed that amplification products arise from the mRNA template at 316 and $372 \mathrm{bp}$ and digestion products arise from the cRNA at $194+122$ and $189+183 \mathrm{bp}$, respectively, for PLC $\beta_{1}$ and $\gamma_{1}$ isozymes. Comparative analysis showed that mRNA levels of PLC $\beta_{1}$ and $\gamma_{1}$ were higher in the hippocampus than in frontal cortex (Figure 5). As noted with the immunolabeling of PLC isozymes, no significant differences were observed in mRNA levels of PLC $\beta_{1}$ or $\gamma_{1}$ isozyme either in the frontal cortex or hippocampus of groups A or B, LH rats as compared with NLH or TC rats (Figure 5). On the other hand, repeated shock (group C rats; IS on days 1 and 7, and tested on day 14) significantly decreased PLC $\beta_{1}$ and $\gamma_{1}$ mRNA levels in the frontal cortex and hippocampus of $\mathrm{LH}$ rats as compared with NLH or TC rats (Figure 5).

\section{DISCUSSION}

The behavioral findings and the observed effects on PLC were highly correlated and were stress paradigm-dependent. The escape latencies and escape failures were clearly different in $\mathrm{LH}$ rats as compared with TC or NLH rats. Whereas escape latencies and escape failures were higher in LH rats, they were similar in NLH and TC rats. A higher escape latency was noted in LH rats exposed to IS on day 1 when tested for escape latency on day 2, but not when these rats were tested on day 4, suggesting that this behavioral deficit does not persist for 4 days after a single-IS paradigm. On the other hand, when rats were exposed to another IS on day 7 in addition to the first IS and were tested on day 14, the escape latency was higher in LH rats as compared with NLH or TC rats. Our observations thus suggest that exposure to a second IS produces a longer-lasting behavioral deficit. This is an important observation, as this model may enable comparison of neurobiological phenomena in acute $v s$ chronic/recurrent depression, which may have different responsive mechanisms.

Our studies of PLC in the three different groups of rats showed that the catalytic activity of PI-PLC was decreased in both membrane and cytosol fractions of the frontal cortex and hippocampus of LH rats subjected to a single stress. Similar results were noted after repeated stress; however, no change was observed when rats given single stress were tested on day 4 . We further examined whether the effect of LH behavior on PI-PLC activity was related to the expression of any specific PLC isozyme. On the basis of sequence homology and localization of structural domains, PLC has been characterized into three major families: PLC $\beta, \delta$, and $\gamma$ (Rebecchi and Pentyala, 2000; Rhee, 2001). All PLC isozymes recognize PIP $_{2}$ as a substrate and carry out $\mathrm{Ca}^{2+}$-dependent hydrolysis of inositol lipids; however, these isozymes are differentially regulated and expressed. The PLC $\beta$ family includes the $150-\mathrm{kDa}$ products of four genes $\left(\beta_{1}-\beta_{4}\right)$. Of these $\beta_{1}, \beta_{3}$, and $\beta_{4}$ are present in the brain. PLC $\beta_{1}$ is highly expressed in the cortex and hippocampus (Ross et al, 1989), whereas expression of PLC $\beta_{2}$ is almost negligible in the cortex and hippocampus (Tanaka and Kondo, 1994). The expression of PLC $\beta_{3}$ is low throughout the brain (Tanaka and Kondo, 1994). The activity of these isoforms is regulated by hormone-receptor complexes through heterotrimeric $\mathrm{G}$ proteins (Kamat and Carpenter, 1997). Both $\mathrm{G}_{\mathrm{q}}$ and $\mathrm{G} \beta \gamma$ proteins activate PLC $\beta$. The PLC $\gamma$ family consists of PLC $\gamma_{1}$ and $\gamma_{2}$. PLC $\gamma_{1}$ is ubiquitously expressed (Rhee et al, 1991), whereas PLC $\gamma_{2}$ expression is confined to the spleen and thymus (Emori et al, 1989). PLC $\gamma$ is regulated by receptors and nonreceptor tyrosine kinases (Rhee, 2001). Little is known about the regulation of PLC $\delta$. Recent studies, however, suggest that 


\section{Frontal Cortex}

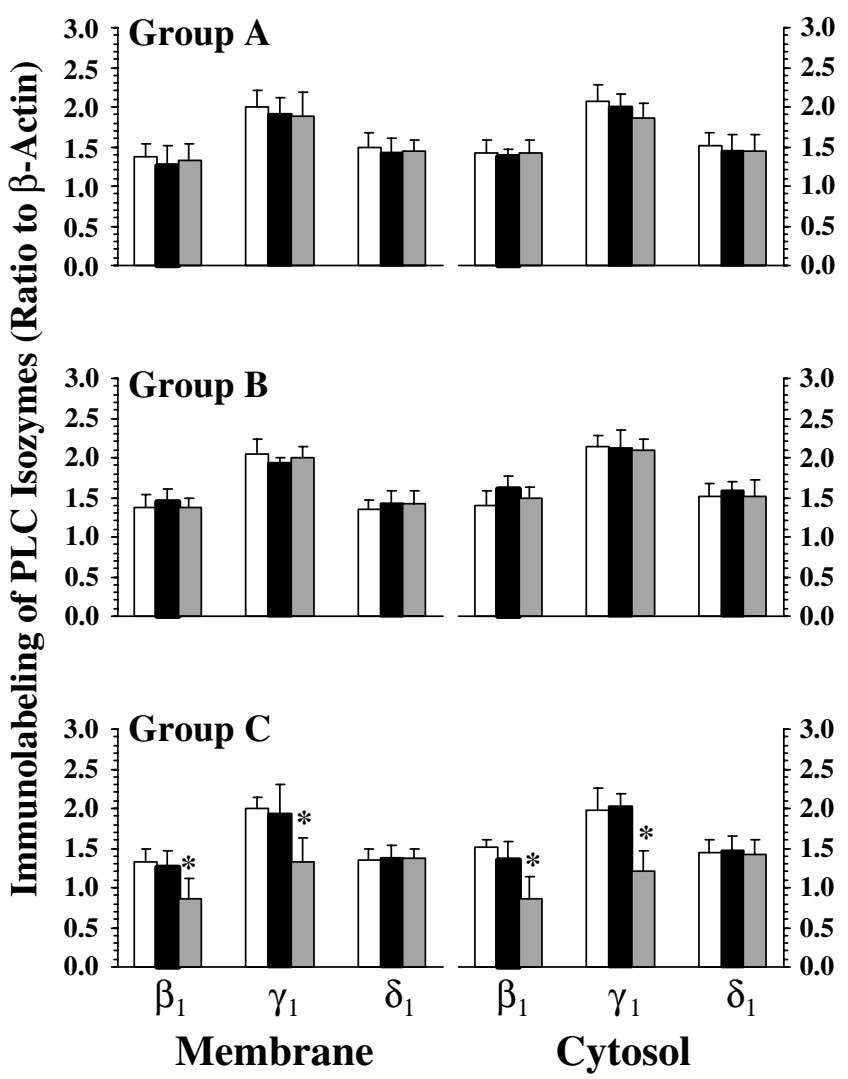

Hippocampus
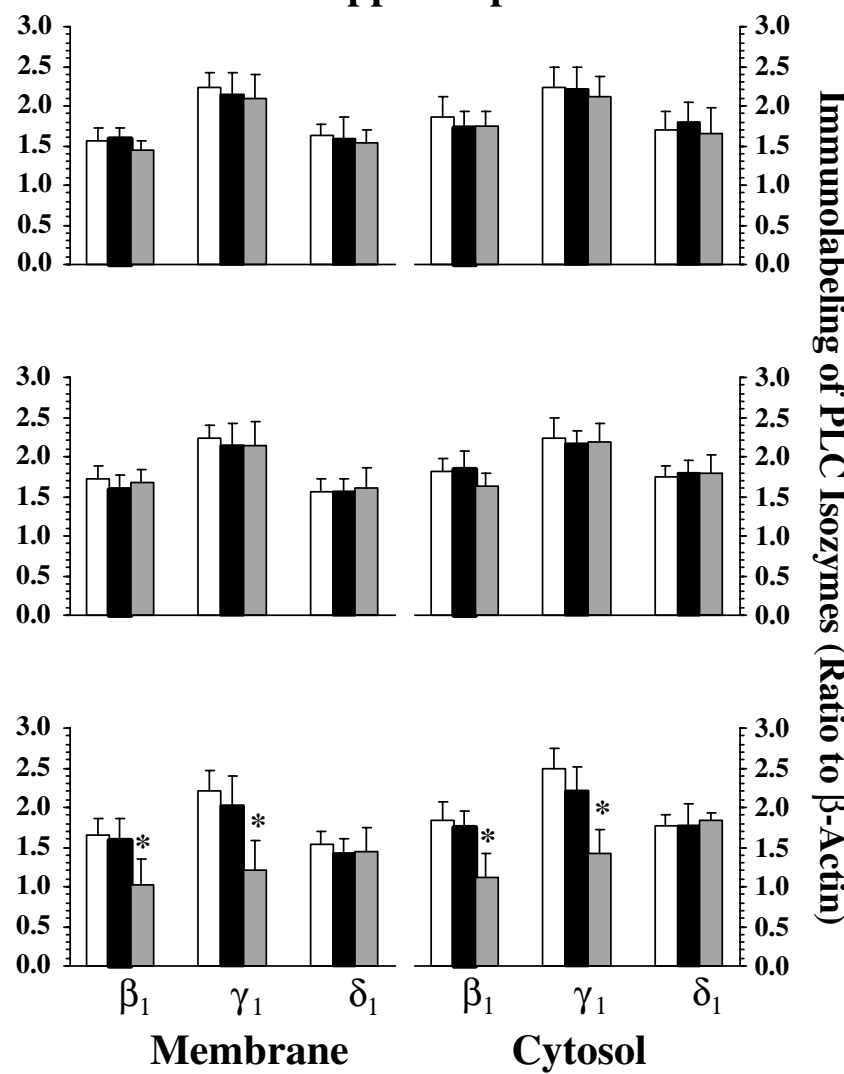

Figure 3 Immunolabeling of PLC isozymes in membrane and cytosol fractions of the frontal cortex and hippocampus of groups A (given inescapable shock on day I and tested for escape latency on day 2), B (given inescapable shock on day I and tested for escape latency on day 4), and C (given inescapable shock on day I and tested for escape latency on day 2; rats were again given shock on day 7 and tested for escape latency on day 8 , and retested on day 14), comprised of TC, NLH, and LH rats. Rats were decapitated $24 \mathrm{~h}$ after the last testing. Values are means \pm SD. Overall group differences in different groups were as follows: Group A (frontal cortex: membrane, PLC $\beta, \mathrm{df}=2,20, \mathrm{~F}=0.55, P=0.58 ; \mathrm{PLC} \gamma, \mathrm{df}=2,20, \mathrm{~F}=0.59, \mathrm{P}=0.56 ; \mathrm{PLC} \delta$, $\mathrm{df}=2,20, \mathrm{~F}=0.08, P=0.92 ;$ cytosol, $\mathrm{PLC} \beta, \mathrm{df}=2,20, \mathrm{~F}=0.18, P=0.83 ; \mathrm{PLC} \gamma, \mathrm{df}=2,20, \mathrm{~F}=2.4, P=0.1 \mathrm{P} ; \mathrm{PLC} \delta, \mathrm{df}=2,20, \mathrm{~F}=0.25, P=0.78 ;$ hippocampus: membrane, $\mathrm{PLC} \beta, \mathrm{df}=2,20, \mathrm{~F}=2.5, \mathrm{P}=0 . \mathrm{I0} ; \mathrm{PLC} \gamma, \mathrm{df}=2,20, \mathrm{~F}=0.69, \mathrm{P}=0.5 \mathrm{I} ; \mathrm{PLC} \delta, \mathrm{df}=2,20, \mathrm{~F}=0.37, \mathrm{P}=0.69 ; \mathrm{cytosol}, \mathrm{PLC} \beta$, $\mathrm{df}=2,20, \mathrm{~F}=0.94, \mathrm{P}=0.40 ; \mathrm{PLC} \gamma, \mathrm{df}=2,20, \mathrm{~F}=0.4 \mathrm{I}, \mathrm{P}=0.67 ; \mathrm{PLC} \delta, \mathrm{df}=2,20, \mathrm{~F}=0.39, \mathrm{P}=0.68$ ); Group $\mathrm{B}$ (frontal cortex: membrane, PLC $\beta, \mathrm{df}=2$, $20, F=0.63, P=0.54 ; P L C \gamma, d f=2,20, F=0.77, P=0.48 ; P L C \delta, d f=2,20, F=0.02, P=0.59 ; c y t o s o l, P L C \beta, d f=2,20, F=2.5, P=0.1 I ; P L C \gamma, d f=2$, $20, \mathrm{~F}=0.06, \mathrm{P}=0.94 ; \mathrm{PLC} \delta, \mathrm{df}=2,20, \mathrm{~F}=0.29, \mathrm{P}=0.75 ;$ hippocampus: membrane, $\mathrm{PLC} \beta, \mathrm{df}=2,20, \mathrm{~F}=1 . \mathrm{I3}, \mathrm{P}=0.34 ; \mathrm{PLC} \gamma, \mathrm{df}=2,20, \mathrm{~F}=0.4$, $P=0.67 ; \mathrm{PLC} \delta, \mathrm{df}=2,20, \mathrm{~F}=0.10, P=0.90 ; \mathrm{cytosol}, \mathrm{PLC} \beta, \mathrm{df}=2,20, \mathrm{~F}=3.05, P=0.07 ; \mathrm{PLC} \gamma, \mathrm{df}=2,20, \mathrm{~F}=0.16, P=0.85 ; \mathrm{PLC} \delta, \mathrm{df}=2,20, \mathrm{~F}=0.08$, $P=0.92$ ); and Group $C$ (frontal cortex: membrane, PLC $\beta, \mathrm{df}=2,20, \mathrm{~F}=10.63, P=0.00 \mathrm{I} ; \mathrm{PLC} \gamma, \mathrm{df}=2,20, \mathrm{~F}=12.92, P<0.00 \mathrm{I} ; \mathrm{PLC} \delta, \mathrm{df}=2,20$, $\mathrm{F}=0.03, \mathrm{P}=0.97$; cytosol, PLC $\beta, \mathrm{df}=2,20, \mathrm{~F}=7.83, \mathrm{P}=0.003 ; \mathrm{PLC} \gamma, \mathrm{df}=2,20, \mathrm{~F}=27.77, \mathrm{P}<0.00 \mathrm{I} ; \mathrm{PLC} \delta, \mathrm{df}=2,20, \mathrm{~F}=0.48, P=0.95 ;$ hippocampus: membrane, PLC $\beta, \mathrm{df}=2,20, \mathrm{~F}=18.33, \mathrm{P}<0.00 \mathrm{I} ; \mathrm{PLC} \gamma, \mathrm{df}=2,20, \mathrm{~F}=19.18, P<0.001 ; \mathrm{PLC} \delta, \mathrm{df}=2,20, \mathrm{~F}=0.49, P=0.62 ; \mathrm{cytosol}, \mathrm{PLC} \beta, \mathrm{df}=2,20$, $\mathrm{F}=18.55, \mathrm{P}<0.00 \mathrm{I} ; \mathrm{PLC} \gamma, \mathrm{df}=2,20, \mathrm{~F}=28.98, P<0.00 \mathrm{I} ; \mathrm{PLC} \delta, \mathrm{df}=2,20, \mathrm{~F}=0.19, P=0.83)$. * $P<0.001$ as compared with $\mathrm{TC}$.

PLC $\delta$ is activated by an atypical G protein, that is, $\mathrm{G}_{\mathrm{h}}$, which acts as a transglutaminase (Murthy et al, 1999) and is a $\mathrm{Ca}^{2+}$ signal amplifier (Allen et al, 1997). In the present study, some interesting observations were noted when the expression of PLC $\beta$, $\gamma$, and $\delta$ isozymes was determined after single and repeated stress.

Whereas repeated stress was associated with a selective decrease in the protein expression of PLC $\beta_{1}$ and $\gamma_{1}$ in membrane and cytosol fractions of the frontal cortex and hippocampus of LH rats, no significant changes were noted in any of the PLC isozymes in LH rats after the single-stress paradigm. With the use of specific primers and quantitative RT-PCR, a concomitant decrease in mRNA levels of the PLC $\beta_{1}$ and $\gamma_{1}$ isozymes was observed in LH rats after repeated stress. Our findings that only PI-PLC activity is decreased in
$\mathrm{LH}$ rats after the single-stress paradigm and that not only PI-PLC activity but also the expression of specific isozymes of PLC are decreased in LH rats after the repeated-stress paradigm clearly demonstrate that PLC is differentially modulated in $\mathrm{LH}$ rats in response to single $v s$ repeated stress.

The changes in PI-PLC activity and in expression of PLC $\beta_{1}$ and $\gamma_{1}$ appear to be specific to $\mathrm{LH}$ behavior, since these changes are very well correlated with the behavioral findings. For example, no changes in PI-PLC activity or in the expression of PLC isozymes were noted in those LH rats who were tested 4 days after a single-IS paradigm, and whose escape latencies were similar to those of TC or NLH rats. On the other hand, changes in PLC occurred only in those $\mathrm{LH}$ rats who showed higher escape latencies, whether 
subjected to a single- or a repeated-IS paradigm. Furthermore, to rule out whether the changes in PLC are nonspecific, namely, due to the stress caused by restraint, tail shock, or testing, TC rats were handled similarly as NLH and LH rats, and NLH rats were given IS, and both TC and $\mathrm{NLH}$ rats were tested for escape behavior.

The observed modulation of PLC in the brain of LH rats is quite intriguing. Very recently, we examined the effects of psychoactive drugs on PI-PLC and observed that chronic administration of antidepressants, such as fluoxetine, desipramine, phenelzine, and the anti-anxiety drug buspirone, to normal rats decreased, whereas administration of

a

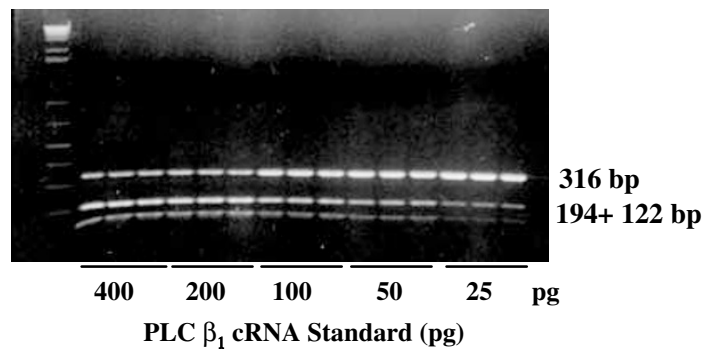

b
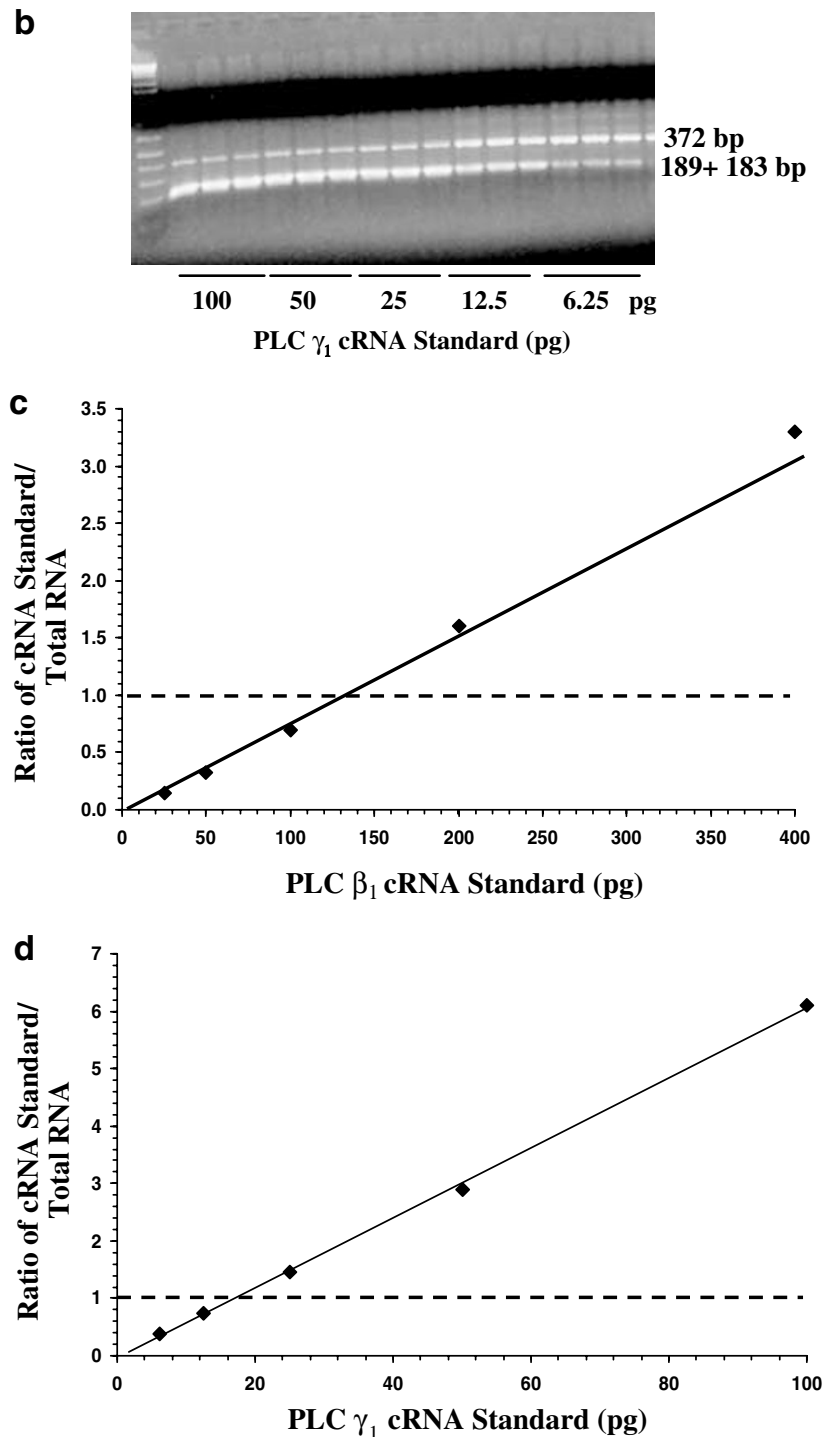

the anxiogenic drug metachlorophenylpiperazine increased, PI-PLC activity as well as expression of the PLC $\beta_{1}$ isozyme in rat cortex and hippocampus, without any change in the expression of PLC $\delta_{1}$ or $\gamma_{1}$ (Dwivedi et al, 2002). Interestingly, $\mathrm{LH}$ rats exhibit anxious behavior, and buspirone was found to attenuate $\mathrm{LH}$ behavior in rats (Drugan et al, 1987). Given that antidepressants and buspirone as well decrease PI-PLC activity and expression of the PLC $\beta_{1}$ isozyme, one might expect the opposite effects on PI-PLC to be associated with LH behavior. However, this was not the case. We found that both antidepressants and LH cause a decrease in PI-PLC. Such findings are not surprising. It has been reported that $5 \mathrm{HT}_{2 \mathrm{~A}}$ receptors are upregulated in depression (Biegon et al, 1987; Arora and Meltzer, 1989a; Hrdina et al, 1995) and that antidepressant administration to normal human controls (Lowther et al, 1994) and electroconvulsive shock (Kellar et al, 1981) to rats also increase $5 \mathrm{HT}_{2 \mathrm{~A}}$ receptors. Similarly, $\beta$-adrenergic receptors are upregulated in the leukocytes of depressed patients (Extein et al, 1979; Carstens et al, 1987; Pandey et al, 1987; Magliozzi et al, 1989) and after antidepressant treatment (Sulser, 1979; Peroutka and Snyder, 1980; Pandey et al, 1985). Although the idea is speculative in nature, it is quite possible that PI-PLC may be regulated differently under the physiological conditions induced by learned helplessness/depression. Whereas PI-PLC may be downregulated after antidepressant administration to wild-type animals, antidepressants may reverse this decrease when given to LH rats. Future studies are needed to clarify this issue.

Interestingly, as mentioned earlier, the single-stress paradigm decreased only PI-PLC activity, whereas repeated stress decreased not only PI-PLC activity but also the expression of PLC $\beta$ and $\gamma$ isozymes. It appears that a decrease in PI-PLC activity after repeated stress may be due to decreased synthesis of PLC $\beta$ and $\gamma$ isozymes. This is further supported by the notion that upon activation PLC is translocated from the membrane to cytosol. Since we observed that PI-PLC activity as well as expression of $\beta$ and $\gamma$ isozymes was decreased in both membrane and cytosol fractions, this supports the possibility that the decrease in PI-PLC activity could be due to the decreased synthesis of these specific PLC isozymes. As far as decrease in PI-PLC activity after single stress is concerned, no

Figure 4 Representative experiments showing competitive PCR analyses for PLC $\beta_{1}$ (a) and $\gamma_{1}$ (b) mRNA content in the frontal cortex of a normal rat brain. Decreasing concentrations of PLC $\beta_{\text {। }}(400-25 \mathrm{pg}$ ) or PLC $\gamma_{1}(100-12.5 \mathrm{pg})$ standard CRNA were added to a constant amount $(\mathrm{I} \mu \mathrm{g})$ of total RNA isolated from the frontal cortex. The mixtures were reverse-transcribed and PCR-amplified in the presence of trace amounts of $\left[{ }^{35} \mathrm{P}\right] \mathrm{dCPT}$; aliquots were digested by Bglll and electrophoresed on $1.5 \%$ agarose gel. The higher molecular size band (316 bp for PLC $\beta_{1}$ and 372 bp for PLC $\gamma_{1}$ ) corresponds to the amplification products arising from the mRNA, whereas the lower bands $\left(194+122\right.$ bp for PLC $\beta_{1}$ and $189+$ $183 \mathrm{bp}$ for PLC $\gamma_{1}$ ) arise from CRNA generated from the internal standard digested by Bglll. Data derived from the agarose gel are plotted as the counts incorporated into the amplified cRNA standard divided by the counts incorporated into the corresponding isozyme mRNA amplification product vs the known amount of internal standard cRNA added to the test sample. The point of equivalence represents the amount of PLC $\beta_{1}$ (c) or PLC $\gamma_{1}$ (d) mRNA. 
TC $(\mathbf{n}=8) \square \operatorname{NLH}(\mathbf{n}=7) \square \operatorname{LH}(\mathbf{n}=8)$
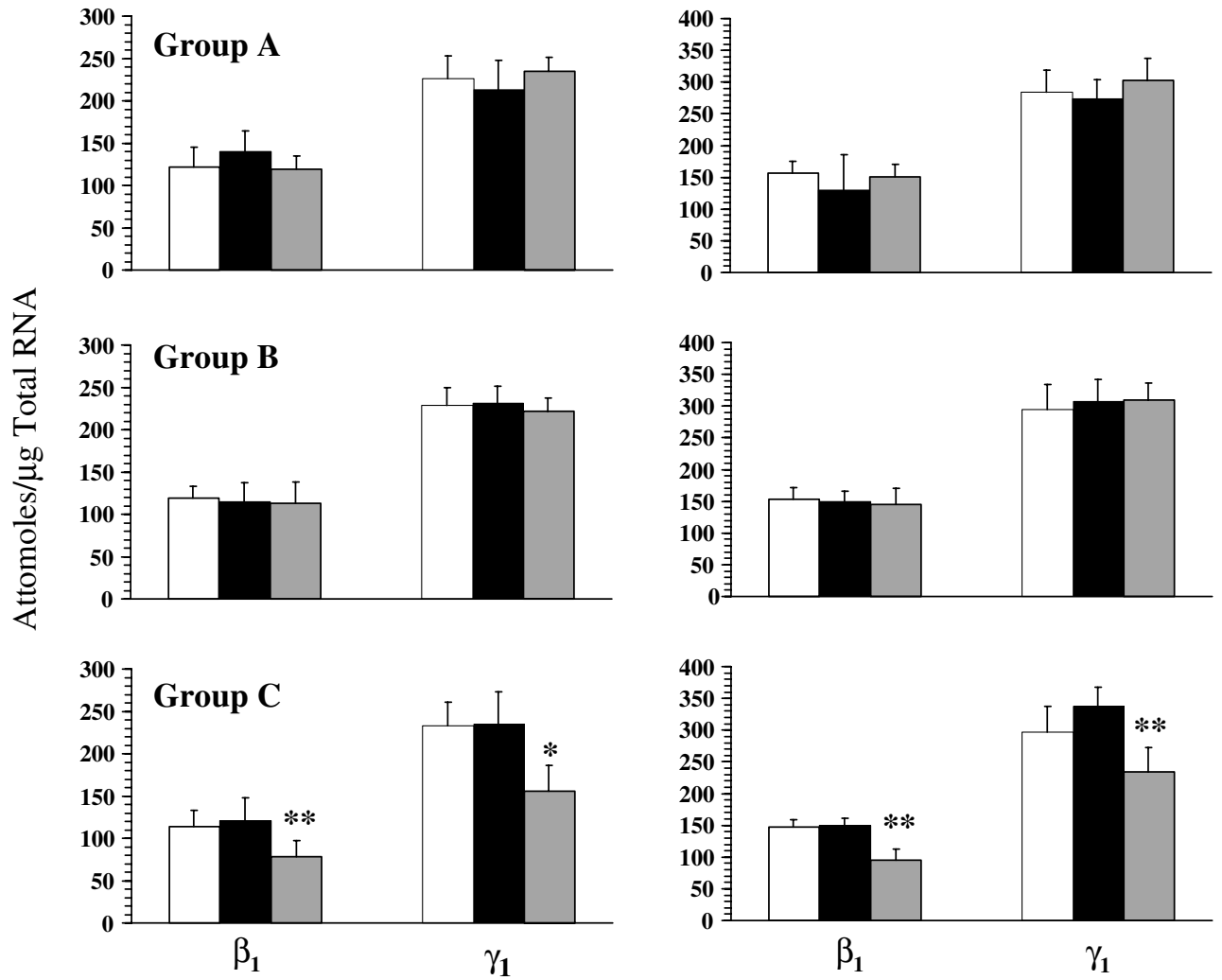

Frontal Cortex

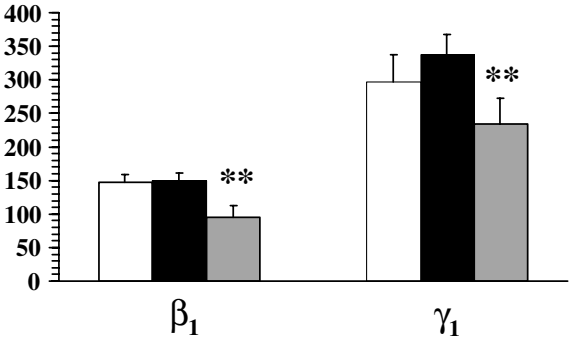

Hippocampus

Figure 5 mRNA levels of PLC isozymes in the frontal cortex and hippocampus of groups A (given inescapable shock on day I and tested for escape latency on day 2), B (given inescapable shock on day I and tested for escape latency on day 4), and C (given inescapable shock on day I and tested for escape latency on day 2; rats were again given shock on day 7 and tested for escape latency on day 8, and re-tested on day I4), comprised of TC, NLH, and $\mathrm{LH}$ rats. Rats were decapitated $24 \mathrm{~h}$ after the last testing. Values are means \pm SD. Overall group differences in different groups were as follows: Group A (frontal cortex: $\mathrm{PLC} \beta, \mathrm{df}=2,20, \mathrm{~F}=1.9, P=0.17 ; \mathrm{PLC} \gamma, \mathrm{df}=2,20, \mathrm{~F}=1.21, P=0.32 ;$ hippocampus: $\mathrm{PLC} \beta, \mathrm{df}=2,20, \mathrm{~F}=0.37, P=0.69 ; \mathrm{PLC} \gamma, \mathrm{df}=2,20$, $\mathrm{F}=1.3, P=0.26$ ); Group $\mathrm{B}$ (frontal cortex: $\mathrm{PLC} \beta, \mathrm{df}=2,20, \mathrm{~F}=0.18, P=0.83 ; \mathrm{PLC} \gamma, \mathrm{df}=2,20, \mathrm{~F}=0.48, P=0.62 ;$ hippocampus: $P L C \beta, \mathrm{df}=2,20$, $\mathrm{F}=0.3 \mathrm{I}, \mathrm{P}=0.74 ; \mathrm{PLC} \gamma, \mathrm{df}=2,20, \mathrm{~F}=0.39, P=0.68$ ); and Group $\mathrm{C}$ (frontal cortex: $\mathrm{PLC} \beta, \mathrm{df}=2,20, \mathrm{~F}=8.34, P=0.002 ; \mathrm{PLC} \gamma, \mathrm{df}=2,20, \mathrm{~F}=15.17$ $P<0.00$ I; hippocampus: PLC $\beta, \mathrm{df}=2,20, \mathrm{~F}=29.0 \mathrm{I}, \mathrm{P}<0.00 \mathrm{I} ; \mathrm{PLC} \gamma, \mathrm{df}=2,20, \mathrm{~F}=\mid 4.61, \mathrm{P}<0.00 \mathrm{I})$. *P $=0.002$; $* * P<0.001$ as compared with TC.

specific explanation is currently available; however, the possibility of a transient effect of acute stress on PI-PLC activity cannot be ruled out.

How PLC is regulated in brain of LH rats is not clear at the present time. In an earlier study, we demonstrated that PLC is regulated in response to glucocorticoids. For example, we found that, whereas the synthetic glucocorticoid dexamethasone increased, corticosterone administration decreased PI-PLC activity and expression of the PLC $\beta_{1}$ isozyme in rat brain (Dwivedi and Pandey, 1999; Dwivedi et al, 2000). In the present study, although we did not find significant differences in the levels of corticosterone among TC, NLH, and LH rats, a much higher level of corticosterone was noted in LH rats; however, due to the large variation, this increase was not significantly different. It is pertinent that a hyperactive hypothalamic-pituitary-adrenal axis has been reported during stress, anxiety, and depressive behavior (Plotsky et al, 1998; Strohle and Holsboer, 2003), which is associated with the release of cortisol. Many studies have shown that the induction of LH behavior is sensitive to the effects of corticosterone (De Kloet et al, 1988; Haracz et al, 1988; Greenberg et al, 1989). Edwards et al (1990) has reported that adrenalectomy increases the number of animals who become helpless, and that this is reversed by corticosterone administration. There is a possibility that PLC might be regulated in response to elevated stress hormones.

Another possibility could be the desensitization of PLC in response to upstream events at the level of neurotransmitters. It is pertinent to mention that a number of studies demonstrate upregulated serotonin $\left(5 \mathrm{HT}_{2 \mathrm{~A}}\right)$ receptors, linked to the phosphoinositide signaling pathway, in postmortem brain of depressed patients and suicide victims (Mann et al, 1986; Arora and Meltzer, 1989b; Arango et al, 1990; Pandey et al, 2002) and in platelets of depressed patients (Pandey et al, 1995; see Mendelson, 2000). It is quite possible that the decrease in PLC may be in response to the activation of $5 \mathrm{HT}_{2 \mathrm{~A}}$ receptors. Although a functional deficit of 5HT in LH rats has been reported (Hellhammer et al, 1984; Petty et al, 1992), the results pertaining to changes in $5 \mathrm{HT}_{2 \mathrm{~A}}$ receptor number in $\mathrm{LH}$ behavior and stress have been inconsistent (Ferretti et al, 1995; Wu et al, 1999). 
Regardless of the mechanisms regulating PLC in brain of $\mathrm{LH}$ rats, it is interesting to note that only PI-PLC activity was decreased after the single-stress paradigm, whereas repeated stress decreased not only PI-PLC activity but also the gene expression of specific PLC isozymes. These results suggest that the induction of LH could be a two-step process, an acute followed by long-term stabilization. It is quite possible that acute stress could be causing transient effects, whereas repeated stress might act at the level of gene expression, whose effects would be longer lasting.

The functional significance of the decrease in PLC associated with $\mathrm{LH}$ behavior is yet to be determined, but it is well established that a wide variety of extracellular signals produce many biological responses by regulating the state of phosphorylation and dephosphorylation of specific proteins, which are then involved in the regulation of cellular functions. It has been shown that PLC is involved in various neuronal functions, such as synthesis and release of neurotransmitters, regulation of receptors and ion channels, growth, differentiation, and gene expression. Given that depression may be associated with cellular adaptation and neuronal plasticity (Malberg and Duman, 2003), a decrease in PLC is quite relevant in depressive behavior. That there is a decrease in PLC $\gamma_{1}$ expression in the brain of LH rats is quite striking. Whereas PLC $\beta_{1}$ is regulated by G-proteincoupled receptors, PLC $\gamma$ is regulated by several tyrosine kinase receptors (Rhee, 2001), including those with trophic activity in brain, such as nerve growth factor and brainderived neurotrophic factor, thus regulating cell division, differentiation, cell survival, and apoptosis. In addition, it has been shown that inhibition of PLC $\gamma$ strongly inhibits the activation of extracellular signal-regulated kinase and Akt in fibroblasts (Amin et al, 2003), which are critical in the regulation of cell survival and apoptosis. As is true for both PLC $\beta$ and $\gamma$ of their role in releasing $\mathrm{Ca}^{2+}$ from intracellular sources, a new role of PLC $\gamma$ has emerged. Recently, Patterson et al (2002) have found that PLC $\gamma$ is essential for the activation of calcium entry into cells after stimulation of cell surface receptors. It is pertinent to mention that disturbances in $\mathrm{Ca}^{2+}$ regulation in depression (Mikuni et al, 1991; Kusumi et al, 1994; Dwivedi et al, 1998; Kusumi et al, 2000; Plein and Berk, 2000; Berk et al, 2001), and recently in lymphocytes of LH rats (Velbinger et al, 2000), have been reported. Also, Turecki et al (1998) have reported evidence that PLC $\gamma_{1}$ may be involved in the predisposition to bipolar disorder of the lithium-responsive patients, suggesting a role of PLC $\gamma_{1}$ in the pathogenesis of affective disorder.

In conclusion, to our knowledge, this is the first study that examines the crucial components of the PI signaling system, that is, PI-PLC, in LH behavior. Our study demonstrates diminished activation of PLC in the brain of LH rats, which apparently has different responsive mechanisms at the level of PLC isozyme expression as a consequence of single $v s$ repeated stress. Whereas single stress causes a decrease in PI-PLC activity, repeated stress causes lower expression of PLC $\beta_{1}$ and $\gamma_{1}$ isozymes as well. Our study not only suggests that alterations in PLC may be important in the pathophysiology of depression and other stress-related disorders but also raises the interesting possibility that PLC may be playing different roles in acute $v s$ recurrent depression.

\section{ACKNOWLEDGEMENTS}

This study is supported by grants from the NIMH (RO1MH 68777; KO1MH01836) and a Young Investigator Award from the American Foundation for Suicide Prevention to Dr Yogesh Dwivedi.

\section{REFERENCES}

Allen V, Swigart P, Cheung R, Cockcroft S, Katan M (1997). Regulation of inositol lipid-specific phospholipase cdelta by changes in $\mathrm{Ca}^{2+}$ ion concentrations. Biochem J 327: 545-552.

Amin AR, Ichigotani Y, Oo ML, Biswas MH, Yuan H, Huang P et al (2003). The PLC-PKC cascade is required for IL-1 $\beta$-dependent Erk and Akt activation: their role in proliferation. Int J Oncol 23: $1727-1731$.

Anisman H, Zacharko RM (1992). Depression as a consequence of inadequate neurochemical adaptation in response to stressors. Br J Psychiatry 160: 36-43.

Arango V, Ernsberger P, Marzuk PM, Chen JS, Tierney H, Stanley $M$ et al (1990). Autoradiographic demonstration of increased serotonin $5 \mathrm{HT}_{2}$ and $\beta$-adrenergic receptor binding sites in the brain of suicide victims. Arch Gen Psychiatry 47: 1038-1047.

Arora RC, Meltzer HY (1989a). Increased serotonin ${ }_{2}\left(5 \mathrm{HT}_{2}\right)$ receptor binding as measured by $\left[{ }^{3} \mathrm{H}\right]$ lysergic diethylamide $\left(\left[{ }^{3} \mathrm{H}\right] \mathrm{LSD}\right)$ in the blood platelets of depressed patients. Life Sci 44: 725-734.

Arora RC, Meltzer HY (1989b). Serotonergic measures in the brains of suicide victims. $5 \mathrm{HT}_{2}$ binding sites in the frontal cortex of suicide victims and control subjects. Am J Psychiatry 146: 730-736.

Berk M, Plein H, Ferreira D (2001). Platelet glutamate receptor supersensitivity in major depressive disorder. Clin Neuropharmacol 24: 129-132.

Biegon A, Weizman A, Karp L, Ram A, Tiano S, Wolff M (1987). Serotonin $5 \mathrm{HT}_{2}$ receptor binding on blood platelets: a peripheral marker for depression? Life Sci 41: 2485-2492.

Carstens ME, Engelbrecht AH, Russell VA, Aalbers C, Gagiano CA, Chalton DO et al (1987). Beta-adrenoceptors on lymphocytes of patients with major depressive disorders. Psychiatry Res 20: 239-248.

De Kloet ER, De Kock S, Schild V, Veldhuis HD (1988). Antiglucocorticoid RU38486 attenuates retention of a behaviour and disinhibits the hypothalamic-pituitary-adrenal axis at different brain sites. Neuroendocrinology 47: 109-115.

Dekker LV, Palmer RH, Parker PJ (1995). The protein kinase C and protein kinase C related gene families. Curr Opin Struct Biol 5: 396-402.

Drugan R, Morrow A, Weizman R, Weizman A, Deutsch S, Crawley $\mathrm{J}$ et al (1989). Stress-induced behavioral depression is associated with a decrease in GABA receptor-mediated chloride ion flux and brain benzodiazepine receptor occupancy. Brain Res 487: 45-51.

Drugan RC, Crawley JN, Paul SM, Skolnick P (1987). Buspirone attenuates learned helplessness behavior in rats. Drug Dev Res 10: 63-67.

Drugan RC, Maier SF (1983). Analgesic and opioid involvement in the shock-elicited activity and escape deficits produced by inescapable shock. Learn Motiv 14: 30-47.

Duman RS, Malberg J, Nakagawa S, D'Sa C (2000). Neuronal plasticity and survival in mood disorders. Biol Psychiatry 48: 732-739.

Dwivedi Y, Agrawal AK, Rizavi HS, Pandey GN (2002). Antidepressants reduce phosphoinositide-specific phospholipase $\mathrm{C}$ (PI-PLC) activity and the mRNA and protein expression of selective PLC $\beta_{1}$ isozyme in rat brain. Neuropharmacology 43: 1269-1279.

Dwivedi Y, Janicak PG, Pandey GN (1998). Elevated $\left[{ }^{3} \mathrm{H}\right]$ inositol 1,4,5-trisphosphate binding sites and expressed inositol 1,4,5- 
trisphophate receptor protein level in platelets of depressed patients. Psychopharmacology (Berl) 138: 47-54.

Dwivedi Y, Mondal AC, Shukla PK, Rizavi HS, Lyons J (2004). Altered protein kinase A in brain of learned helpless rats: effects of acute and repeated stress. Biol Psychiatry 56: 30-40.

Dwivedi Y, Pandey GN (1999). Repeated administration of dexamethasone increases phosphoinositide-specific phospholipase $\mathrm{C}$ activity and mRNA and protein expression of the phospholipase $\mathrm{C} \beta_{1}$ isozyme in rat brain. J Neurochem 73: 780-790.

Dwivedi Y, Rizavi HS, Rao JS, Pandey GN (2000). Modifications in the phosphoinositide signaling pathway by adrenal glucocorticoids in rat brain: focus on phosphoinositide-specific phospholipase C and inositol 1,4,5-trisphosphate. J Pharmacol Exp Ther 295: 244-254.

Edwards E, Harkins K, Wright G, Henn FA (1990). Effects of bilateral adrenalectomy on the induction of learned helplessness behavior. Neuropsychopharmacology 3: 109-114.

Emori Y, Homma Y, Sorimachi H, Kawasaki H, Nakanishi O, Suzuki K et al (1989). A second type of rat phosphoinositidespecific phospholipase $C$ containing a src-related sequence not essential for phosphoinositide-hydrolyzing activity. J Biol Chem 264: 21885-21890.

Extein I, Tallman J, Smith CC, Goodwin FK (1979). Changes in lymphocyte beta-adrenergic receptors in depression and mania. Psychiatry Res 1: 191-197.

Ferretti C, Blengio M, Gamalero SR, Ghi P (1995). Biochemical and behaviour changes induced by acute stress in a chronic variate stress model of depression: the effect of amitriptyline. Eur $J$ Pharmacol 280: 19-26.

Grahn RE, Hammack SE, Will MJ, O'Connor KA, Deak T, Sparks PD et al (2002). Blockade of $\alpha_{1}$-adrenoreceptors in the dorsal raphe nucleus prevents enhanced conditioned fear and impaired escape performance following uncontrollable stressor exposure in rats. Behav Brain Res 134: 387-392.

Greenberg L, Edwards E, Henn FA (1989). Dexamethasone suppression test in helpless rats. Biol Psychiatry 26: 530-532.

Haracz JL, Minor TR, Wilkins JN, Zimmermann EG (1988). Learned helplessness: an experimental model of the DST in rats. Biol Psychiatry 23: 388-396.

Hellhammer DH, Rea MA, Bell M, Belkien L, Ludwig M (1984). Learned helplessness: effects on brain monoamines and the pituitary-gonadal axis. Pharmacol Biochem Behav 21: 481-485.

Henn FA, Edwards E, Muneyyirci J (1993). Animal models of depression. Clin Neurosci 1: 152-156.

Hrdina PD, Bakish D, Chudzik J, Ravindran A, Lapierre YD (1995). Serotonergic markers in platelets of patients with major depression: upregulation of $5 \mathrm{HT}_{2}$ receptors. J Psychiatry Neurosci 20: 11-19.

Jesberger JA, Richardson JS (1985). Animal models of depression: parallels and correlates to severe depression in humans. Biol Psychiatry 20: 764-784.

Kamat A, Carpenter G (1997). Phospholipase C- $\gamma_{1}$ : regulation of enzyme function and role in growth factor-dependent signal transduction. Cytokine Growth Factor Rev 8: 109-117.

Kellar KJ, Cascio CS, Butler JA, Kurtzke RN (1981). Differential effects of electroconvulsive shock and antidepressant drugs on serotonin $_{2}$ receptors in rat brain. Eur J Pharmacol 69: 515-518.

Kusumi I, Koyama T, Yamashita I (1994). Serotonin-induced platelet intracellular calcium mobilization in depressed patients. Psychopharmacology (Berl) 113: 322-327.

Kusumi I, Suzuki K, Sasaki Y, Kameda K, Koyama T (2000). Treatment response in depressed patients with enhanced $\mathrm{Ca}$ mobilization stimulated by serotonin. Neuropsychopharmacology 23: 690-696.

Lowther S, De Paermentier F, Crompton MR, Katona CL, Horton RW (1994). Brain 5-HT2 receptors in suicide victims: violence of death, depression and effects of antidepressant treatment. Brain Res 642: 281-289.

Magliozzi JR, Gietzen D, Maddock RJ, Haack D, Doran AR, Goodman $\mathrm{T}$ et al (1989). Lymphocyte beta-adrenoreceptor density in patients with unipolar depression and normal controls. Biol Psychiatry 26: 15-25.

Maier SF, Grahn RE, Watkins LR (1995). 8-OH-DPAT microinjected in the region of the dorsal raphe nucleus blocks and reverses the enhancement of fear conditioning and interference with escape produced by exposure to inescapable shock. Behav Neurosci 109: 404-412.

Malberg JE, Duman RS (2003). Cell proliferation in adult hippocampus is decreased by inescapable stress: reversal by fluoxetine treatment. Neuropsychopharmacology 28: 1562-1571.

Mann JJ, Stanley M, BcBride PA, McEwen BS (1986). Increased serotonin $_{2}$ and $\beta$-adrenergic receptor binding in the frontal cortices of suicide victims. Arch Gen Psychiatry 43: 954-959.

Maswood S, Barter JE, Watkins LR, Maier SF (1998). Exposure to inescapable but not escapable shock increases extracellular levels of 5HT in the dorsal raphe nucleus of the rat. Brain Res 783: $115-120$.

Mendelson SD (2000). The current status of the platelet $5 \mathrm{HT}_{2 \mathrm{~A}}$ receptor in depression. J Affect Disord 57: 13-24.

Mikuni M, Kusumi I, Kagaya A, Kuroda Y, Mori H, Takahashi K (1991). Increased $5 \mathrm{HT}_{2}$ receptor function as measured by serotonin-stimulated phosphoinositide hydrolysis in platelets of depressed patients. Prog Neuropsychopharmacol Biol Psychiatry 15: 49-61.

Minor T, Pelleymounter M, Maier S (1988). Uncontrollable shock, forebrain norepinephrine and stimulus selection during choiceescape learning. Psychobiology 16: 135-145.

Minor TR, Rowe MK, Soames Job RF, Ferguson EC (2001). Escape deficits induced by inescapable shock and metabolic stress are reversed by adenosine receptor antagonists. Behav Brain Res 120: 203-212.

Murthy SN, Lomasney JW, Mak EC, Lorand L (1999). Interactions of $\mathrm{G}(\mathrm{h}) /$ transglutaminase with phospholipase Cdelta1 and with GTP. Proc Natl Acad Sci USA 96: 11815-11819.

Nestler EJ, Gould E, Manji H, Buncan M, Duman RS, Greshenfeld $\mathrm{H}$ et al (2002). Preclinical models: status of basic research in depression. Biol Psychiatry 52: 503-528.

Pandey GN, Brown B, Davis JM (1985). Effect of treatment with some atypical antidepressants on $\left[{ }^{3} \mathrm{H}\right] \mathrm{DHA}$ binding in rat brain. Drug Dev Res 5: 251-259.

Pandey GN, Dwivedi Y, Pandey SC, Teas SS, Conley RR, Roberts RC et al (1999). Low phosphoinositide-specific phospholipase $C$ activity and expression of phospholipase $C \beta_{1}$ protein in the prefrontal cortex of teenage suicide subjects. Am J Psychiatry 156: 1895-1901.

Pandey GN, Dwivedi Y, Rizavi HS, Ren X, Pandey SC, Pesold C et al (2002). Higher expression of serotonin $5 \mathrm{HT}_{2 \mathrm{~A}}$ receptors in the postmortem brains of teenage suicide victims. Am J Psychiatry 159: 419-429.

Pandey GN, Janicak PG, Davis JM (1987). Decreased betaadrenergic receptors in the leukocytes of depressed patients. Psychiatry Res 22: 265-273.

Pandey GN, Pandey SC, Dwivedi Y, Sharma RP, Janicak PG, Davis JM (1995). Platelet serotonin ${ }_{2 \mathrm{~A}}$ receptors: a potential biological marker for suicidal behavior. Am J Psychiatry 152: 850-855.

Patterson RL, van Rossum DB, Ford DL, Hurt KJ, Bae SS, Suh PG et al (2002). Phospholipase C-gamma is required for agonistinduced $\mathrm{Ca}^{2+}$ entry. Cell 111: 529-541.

Peroutka SJ, Snyder SH (1980). Long-term antidepressant treatment decreases spiroperidol-labeled serotonin receptor binding. Science 210: 88-90.

Petty F, Kramer G, Wilson L (1992). Prevention of learned helplessness: in vivo correlation with cortical serotonin. Pharmacol Biochem Behav 43: 361-367. 
Petty F, Kramer G, Wilson L, Chae Y-L (1993). Learned helplessness and in vivo hippocampal norepinephrine release. Pharmacol Biochem Behav 46: 231-235.

Petty F, Sherman AD (1983). Learned helplessness induction decreases in vivo cortical serotonin release. Pharmacol Biochem Behav 18: 649-650.

Plein H, Berk M (2000). Changes in the platelet intracellular calcium response to serotonin in patients with major depression treated with electroconvulsive therapy: state or trait marker status. Int Clin Psychopharmacol 15: 93-98.

Plotsky PM, Owens MJ, Nemeroff CB (1998). Psychoneuroendocrinology of depression. Hypothalamic-pituitary-adrenal axis. Psychiatr Clin North Am 21: 293-307.

Rebecchi MJ, Pentyala SN (2000). Structure, function, and control of phosphoinositide-specific phospholipase C. Pharmacol Rev 80: 1291-1335.

Rhee SG (2001). Regulation of phosphoinositide-specific phospholipase C. Annu Rev Biochem 70: 281-312.

Rhee SG, Kim H, Suh P-G, Choi WC (1991). Multiple forms of phosphoinositide-specific phospholipase $\mathrm{C}$ and different modes of activation. Biochem Soc Trans 19: 337-341.
Ross CA, MacCumber MW, Glatt CE, Snyder SH (1989). Brain phospholipase C isozymes: differential mRNA localizations by in situ hybridization. Proc Natl Acad Sci USA 86: 2923-2927.

Strohle A, Holsboer F (2003). Stress responsive neurohormones in depression and anxiety. Pharmacopsychiatry 36: S207-S214.

Sulser F (1979). New perspectives on the mode of action of antidepressant drugs. Trends Pharmacol Sci 12: 92-94.

Tanaka O, Kondo H (1994). Localization of mRNA for three novel members $\left(\beta_{3}, \beta_{4}\right.$ and $\left.\gamma_{2}\right)$ of phospholipase $C$ family in mature rat brain. Neurosci Lett 182: 17-20.

Turecki G, Grof P, Cavazzoni P, Duffy A, Grof E, Ahrens B et al (1998). Evidence for a role of phospholipase $C-\gamma_{1}$ in the pathogenesis of bipolar disorder. Mol Psychiatry 3: 534-538.

Velbinger K, De Vry J, Jentzsch K, Eckert A, Henn F, Muller WE (2000). Acute stress induced modifications of calcium signaling in learned helpless rats. Pharmacopsychiatry 33: 132-137.

Weiss J, Stone E, Harrell N (1970). Coping behavior and brain norepinephrine levels in rats. J Comp Physiol Psychol 72: 153-160.

Wu J, Kramer GL, Kram M, Steciuk M, Crawford IL, Petty F (1999). Serotonin and learned helplessness: a regional study of $5 \mathrm{HT}_{1 \mathrm{~A}}$, $5 \mathrm{HT}_{2 \mathrm{~A}}$ receptors and the serotonin transport site in rat brain. J Psychiatr Res 33: 17-22. 